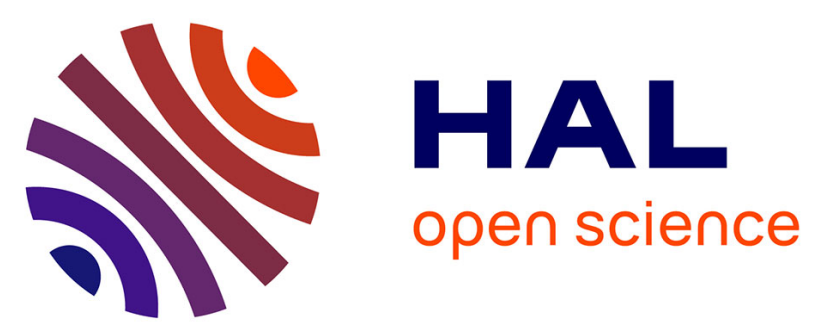

\title{
A complex 1;19;11 translocation involving the gene in a patient with congenital acute monoblastic leukemia identified by molecular and cytogenetic techniques
}

Etienne Braekeleer, Claus Meyer, Nathalie Douet-Guilbert, Frédéric Morel, Marie-Josée Bris, Rolf Marschalek, Claude Férec, Marc Braekeleer

\section{To cite this version:}

Etienne Braekeleer, Claus Meyer, Nathalie Douet-Guilbert, Frédéric Morel, Marie-Josée Bris, et al.. A complex 1;19;11 translocation involving the gene in a patient with congenital acute monoblastic leukemia identified by molecular and cytogenetic techniques. Annals of Hematology, 2008, 88 (8), pp.795-797. 10.1007/s00277-008-0656-8 . hal-00535011

\author{
HAL Id: hal-00535011 \\ https://hal.science/hal-00535011
}

Submitted on 11 Nov 2010

HAL is a multi-disciplinary open access archive for the deposit and dissemination of scientific research documents, whether they are published or not. The documents may come from teaching and research institutions in France or abroad, or from public or private research centers.
L'archive ouverte pluridisciplinaire HAL, est destinée au dépôt et à la diffusion de documents scientifiques de niveau recherche, publiés ou non, émanant des établissements d'enseignement et de recherche français ou étrangers, des laboratoires publics ou privés. 


\title{
A complex 1;19;11 translocation involving the $M L L$ gene in a patient with congenital acute monoblastic leukemia identified by molecular and cytogenetic techniques
}

\author{
Etienne De Braekeleer • Claus Meyer • \\ Nathalie Douet-Guilbert • Frédéric Morel • \\ Marie-Josée Le Bris • Rolf Marschalek • Claude Férec • \\ Marc De Braekeleer
}

Received: 18 August 2008 / Accepted: 25 November 2008/Published online: 24 December 2008

(C) Springer-Verlag 2008

\begin{abstract}
Dear Editor,
Translocations involving chromosomal band 11q23 are found in most of the infant acute lymphoblastic leukemia and in acute myeloblastic leukemia. The majority of these translocations lead to the rearrangement of the $M L L$ gene and the formation of new chimeric genes [1]. We report here a case of congenital acute monoblastic leukemia and myeloid sarcoma associated with an apparent $\mathrm{t}(1 ; 11)(\mathrm{p} 36$; q23) which proved to be in fact a complex $1 ; 19 ; 11$ translocation.

This female child was born after a pregnancy of 33 weeks and 6 days complicated by gravidic toxemia and hydramnios. At birth, the baby was cyanosed and showed no reaction to stimuli. She had disseminated intravascular
\end{abstract}

E. De Braekeleer $\cdot$ N. Douet-Guilbert $\cdot$ F. Morel $\cdot$

M. De Braekeleer

Laboratoire de Cytogénétique, Faculté de Médecine et des

Sciences de la Santé, Université de Bretagne Occidentale,

22, avenue Camille Desmoulins,

CS 93837 F-29238 Brest Cedex 3, France

E. De Braekeleer · N. Douet-Guilbert · F. Morel • C. Férec $\cdot$

M. De Braekeleer $(\bowtie)$

Institut National de la Santé et de la Recherche Médicale (INSERM),

U613 Brest, France

e-mail: marc.debraekeleer@univ-brest.fr

C. Meyer $\cdot$ R. Marschalek

Institute of Pharmaceutical Biology/DCAL/ZAFES,

JWG-University of Frankfurt,

Frankfurt/Main, Germany

N. Douet-Guilbert · F. Morel · M.-J. Le Bris • M. De Braekeleer Service de Cytogénétique, Cytologie et Biologie

de la Reproduction, Hôpital Morvan,

CHU Brest, France coagulation with petechiae and hematoma on the neck and the limbs. Cutaneous tumors were observed on the abdomen, the right arm and the left thigh. Her hematological data were as follows: hemoglobin $14 \mathrm{~g} / \mathrm{dl}$, white blood cells (WBC) $162 \times 10^{9} / \mathrm{L}$ with $0.5 \%$ neutrophils, $0.5 \%$ eosinophils, $9.5 \%$ lymphocytes, $8 \%$ monocytes and $80 \%$ monoblasts and promonocytes, and platelets $50 \times 10^{9} / \mathrm{L}$. A diagnosis of acute monoblastic leukemia (FAB type M5) was made. The biopsy of one cutaneous tumor showed a massive derma infiltration by monoblasts; therefore, these skin tumors were considered to be myeloid sarcomas. Palliative care solely was applied. The child developed acute renal insufficiency and massive cerebral hemorrhage, of which she died $24 \mathrm{~h}$ after birth [2].

Cytogenetic analysis was performed on bone marrow cells with standard techniques. We observed a translocation which appeared to be balanced in R-banding between chromosomes 1 and 11; thus, the karyotype was written as 46,XX,t(1;11)(p36.2;q23). FISH analysis using the LSI $M L L$ dual color probe (Abbott, Rungis, France) confirmed the disruption of the $M L L$ gene. It showed the translocation of the $3^{\prime}$ region of $M L L$ (red signal) to the derivative chromosome 1 while the $5^{\prime}$ region (green signal) remained on the der(11).

We then used long-distance inverse PCR (LDI-PCR) to identify the $M L L$ fusion partner involved in the chromosomal translocation of that particular patient [3]. Genomic DNA was isolated from methanol/acetic acid-fixed cells of leukemia patient that were stored at $-20^{\circ} \mathrm{C}$. DNA was extracted using the QIAamp DNA mini kit (Qiagen GmbH, Hilden, Germany) according to the manufacturer recommendations. After DNA digestion, resulting DNA fragments were re-ligated to form DNA circles prior to LDIPCR studies. LDI-PCR reactions were performed as 


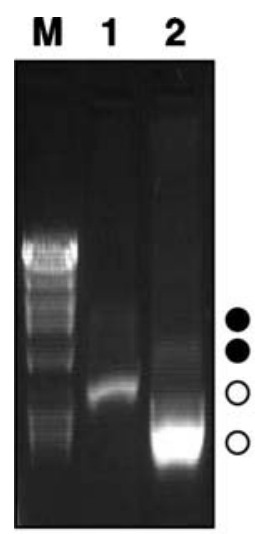

LDI-PCR

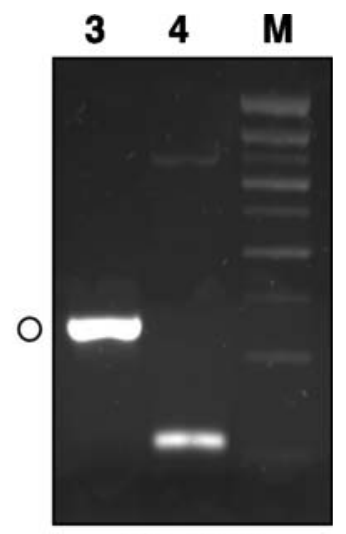

RT-PCR
Fig. 1 Molecular analyses. The DNA sample was treated and analyzed as described. Briefly, $1 \mu \mathrm{g}$ of genomic DNA was digested with restriction enzymes and re-ligated to form DNA circles before LDI-PCR using $M L L$-specific primers. Restriction polymorphic PCR amplimers were isolated from the gel and subjected to DNA sequence analyses to obtain the patient-specific fusion sequences. Left panel LDI-PCR of analyzed patient; black dots $M L L$ wild type bands in lanes 1 and 2. White dots rearranged $M L L$ alleles in lanes 1 and 2. Right panel RT-PCR analysis of patient demonstrating the $M L L-E L L$ fusion (lane 3); lane 4 RT-PCR analysis of an another patient bearing an $M L L-E L L$ fusion that served as positive control; $M$ DNA size markers

described recently [3] and according to the recommendations of the manufacturer (Triple Master Kit, Eppendorf). PCR amplimers were cut off the gel and subjected to sequence analyses (Fig. 1a, left panel). Sequence analysis revealed that the $5^{\prime}$ region of $M L L$ (break in intron 9) was fused in-frame with the 3 ' region of ELL (break in intron 5), a gene located in chromosomal band 19p13.11.

Since cytogenetic analysis revealed a $46, \mathrm{XX}, \mathrm{t}(1 ; 11)$ (p36.2;q23) karyotype, however, the MLL gene was fused to the ELL gene located on chromosome 19p13.11, we started to re-investigate the genomic rearrangement in more detail by using a combination of two BAC clones. The first one, RP11-937I20 (labeled in Spectrum orange), spans the ELL gene, and the second one, RP11-91A14, (labeled in FITC), covers the $M L L$ gene. Two green signals (one on the normal chromosome 11 and one on the der(1)), two red signals (one on the normal chromosome 19 and one on the der(19)) and one yellow signal on the der(11) were seen (Fig. 2). These data confirmed a complex $M L L$ rearrangement, involving loci at 1p36,11q23 and 19p13.11. In order to clarify its true nature, FISH using subtelomeric probes for chromosomes 1 and 19 (Abbott, Rungis, France) was performed. It showed the presence of $1 \mathrm{p}$ subtelomeric sequences on chromosome 19 and of $19 p$ subtelomeric sequences on chromosome 11. Therefore, we reclassified the chromosomal abnormality as a three-way translocation, $\mathrm{t}(1 ; 19 ; 11)(\mathrm{p} 36 ; \mathrm{p} 13.11 ; \mathrm{q} 23)$.

To verify the $M L L-E L L$ fusion on a more functional level, total RNA was also isolated from methanol/aceticacid-fixed cells with RNeasy Mini kit (Qiagen), then reverse transcribed with Omniscript Reverse transcription kit (Qiagen) [4]. The MLL forward primer was: 5'CAGAGCAGAGCAAACAGAAAA-3' and ELL reverse primer was: 5'-CTCTCCGTGCTCACAGTCTC-3'. The $M L L-E L L$ transcript fusion was amplified by HotStarTaq polymerase (Qiagen) with these conditions (Applied Biosystems 9700 ): $15 \mathrm{~min}$ at $95^{\circ} \mathrm{C} ; 35$ cycles at $94^{\circ} \mathrm{C}$ for $30 \mathrm{~s}$, $58^{\circ} \mathrm{C}$ for $45 \mathrm{~s}$ and $72^{\circ} \mathrm{C}$ for $1 \mathrm{~min} 30 \mathrm{~s}$; extension at $72^{\circ} \mathrm{C}$ for $5 \mathrm{~min}$. PCR products were analyzed on a $2 \%$ agarose gel and visualized by ethidium bromide staining. Thus, the genomic $M L L-E L L$ fusion gene is readily expressed and the presence of the resulting $M L L-E L L$ fusion mRNA was confirmed in the patient cells (Fig. 1, right panel).

Several attempts to identify the missing two other fusion alleles (a gene located at 1p36 fused to ELL, MLL fused to a gene located at $1 \mathrm{p} 36$ ) failed so far, although we tested thoroughly for it. This might be due to ligation products,
Fig. 2 FISH with BAC clones RP11-937I20 (labeled in Spectrum Orange) and RP11-91A14 (labeled in FITC) showing two green signals, two red signals and one yellow signal. Chromosomes are depicted on the right. Beside the normal chromosomes 1,11 and 19 , all three derivative chromosomes are shown. Due to the two different fluorescent markers, der(1) is giving a green signal, der(19) a red signal and der(11) a yellow signal
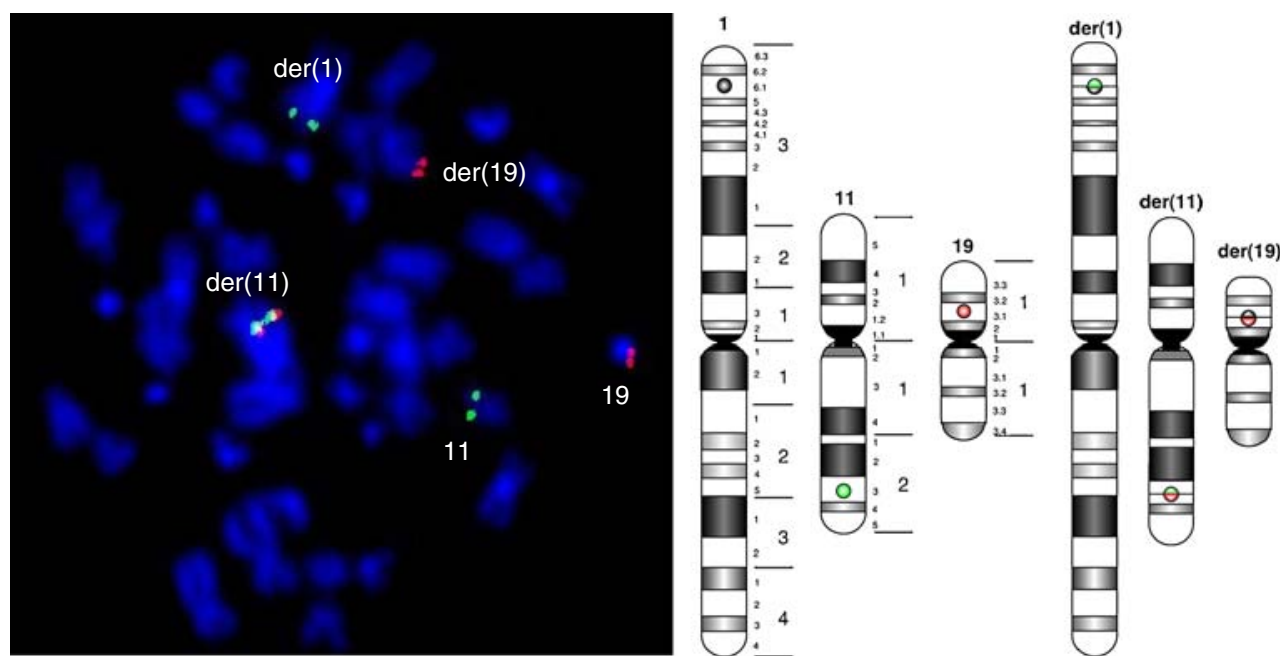
used as template for LDI-PCR experiments, which were too long to obtain appropriate PCR amplimers. Another explanation might be that this complex translocation was accompanied by deletion events that resulted in loss of primer binding sites necessary to generate PCR amplimers. Thus, FISH probes may still be able to bind, but PCR experiments remained negative.

The ELL gene (19p13.11) is frequently identified in $M L L$-rearranged leukemia patients ( $\sim 5 \%)$ [5] and associated with the development of acute myeloblastic leukemia. $M L L-E L L$ fusions are described in childhood $(\sim 11 \%)$ and adult (9\%) AML patients [6]. Noteworthy is that $M L L-E L L$ fusion has a peak incidence in elderly childhood and adult AML patients. $M L L-E L L$ is also frequently identified in secondary AML patients where $M L L-E L L$ fusion displays an overall frequency of about $30 \%$ [7]. The combination of molecular and FISH techniques allowed the chromosomal rearrangement observed in our patient to be classified as a three-way translocation, $\mathrm{t}(1 ; 19 ; 11)(\mathrm{p} 36 ; \mathrm{p} 13.11 ; \mathrm{q} 23)$, with one $M L L-E L L$ fusion allele. This new abnormality might be considered as a complex $t(11 ; 19)$, which was undetected in conventional cytogenetics and resulted in a severe "prenatal AML" disease phenotype.

From the presented data, the following conclusions can be drawn: (1) the analyzed patient contains, as demonstrated by FISH, three independent chromosomal fusion sites involving the chromosomal regions 1p36, 11q23 and 19p13.11; (2) although the sole fusion between 11q23 $(M L L)$ and 19p13.11 (ELL) was successfully analyzed at the DNA and RNA level, we assume that there are additional mutations that resulted in the severe prenatal AML disease phenotype; (3) these mutations may include yet unknown gene fusions (gain-of-function) or deletion of tumor suppressor genes (loss-of-function) located in either of these chromosomal regions. As a matter of fact, several interesting candidate genes are located at $1 \mathrm{p} 36$, as e.g. HES4 (hairy and enhancer of split 4), CCNL2 (cyclin L2), VWA1 (von Willebrand factor A domain containing 1), HES5 (hairy and enhancer of split 5), WDR8 (WD repeat domain 8), TP73 (tumor protein p73), HES3 (hairy and enhancer of split 3), CASP9 (caspase 9, apoptosis-related cysteine peptidase), RUNX3 (runt-related transcription factor 3) and ID3 (inhibitor of DNA binding 3, dominant negative helix-loop-helix protein). Further work focusing on that $1 \mathrm{p} 36$ region will presumably unravel the underlying genetic mechanisms in that particular leukemia patient. This will allow drawing conclusions on synergistic mutations for $M L L$ rearrangements.

EDB is the recipient of a doctoral studentship from the "Association de Transfusion Sanguine et de Biogénétique Gaetan Saleun". This work has been funded in part by the "Ligue contre le Cancer-Comité du Finistère" and by grant 107819 from the Deutsche Krebshilfe to RM.

\section{References}

1. De Braekeleer M, Morel F, Le Bris MJ, Herry A, DouetGuilbert N (2005) The MLL gene and translocations involving chromosomal band 11q23 in acute leukemia. Anticancer Res 25:1931-1944

2. Douet-Guilbert N, Morel F, Le Bris MJ, Sassolas B, Giroux JD, De Braekeleer M (2005) Rearrangement of $M L L$ in a patient with congenital acute monoblastic leukemia and granulocytic sarcoma associated with a $\mathrm{t}(1 ; 11)(\mathrm{p} 36 ; \mathrm{q} 23)$ translocation. Leuk Lymphoma 46:143-146, doi:10.1080/104281904000010783

3. Meyer C, Schneider B, Reichel M, Angermueller S, Strehl S, Schnittger S, Schoch C, Jansen MW, van Dongen JJ, Pieters R, Haas OA, Dingermann T, Klingebiel T, Marschalek R (2005) Diagnostic tool for the identification of MLL rearrangements including unknown partner genes. Proc Natl Acad Sci USA 102:449-454, doi:10.1073/pnas.0406994102

4. Strehl S, Konig M, Mann G, Haas OA (2001) Multiplex reverse transcriptase-polymerase chain reaction screening in childhood acute myeloblastic leukemia. Blood 97:805-808, doi:10.1182/ blood.V97.3.805

5. Meyer C, Schneider B, Jakob S, Strehl S, Attarbaschi A, Schnittger S, Schoch C, Jansen MWJC, van Dongen JJM, den Boer ML, Pieters R, Ennas MG, Angelucci E, Koehl U, Greil J, Griesinger F, zur Stadt U, Eckert C, Szczepanski T, Niggli FK, Schafer BW, Kempski H, Brady HJM, Zuna J, Trka J, Nigro LL, Biondi A, Delabesse E, MacIntyre E, Stanulla M, Schrappe M, Haas OA, Burmeister T, Dingermann T, Klingebiel T, Marschalek R (2006) The MLL recombinome of acute leukemias. Leukemia 20:777784, doi:10.1038/sj.leu.2404150

6. Krivtsov AV, Armstrong SA (2007) MLL translocations, histone modifications and leukaemia stem-cell development. Nat Rev Cancer 7:823-833, doi:10.1038/nrc2253

7. Daser A, Rabbitts TH (2005) The versatile mixed lineage leukaemia gene MLL and its many associations in leukaemogenesis. Semin Cancer Biol 15:175-188, doi:10.1016/j.semcancer. 2005.01.007 